\title{
The Application of Law and Resolving Mechanism to Deal with Violence in Debt Collection in Private Lending
}

\author{
Mengbing Tong \\ School of administrative law, Southwest University of Political Science \& Law, Chongqing 401120, China \\ tongmengbing@foxmail.com
}

Keywords: Private lending, violent debt collection, application of law, resolving mechanism.

\begin{abstract}
Violence in debt collection has been brought into spotlight in the judicial community because of the case of "Yu Huan", which caused severe psychological and mental damage to the debtors. This paper presents the legal application and resolving mechanism of violence in debt collection of private lending, introduces the basic theory of private lending and violent debt collection, and analyses the current situation of domestic and foreign research on violence and debt collection. Based on the case of "Yu Huan", it further discusses the typical cases of violence in private lending and the applications of law in this certain issue. Finally, the paper proposes the resolving mechanism and feasible suggestion of violent debt collection.
\end{abstract}

\section{Fundamental theories of private lending and violent debt collection}

\subsection{Fundamental theories of private lending and violent debt collection}

In March of 2017, murder of the loan shark thug after lewd acts against mother has caused China's social media abuzz [1]. Female entrepreneur Su Yinxia has mortgaged private loan from creditor Wu Xuezhan with real estate but did not pay off the mortgage after Wu dunning for the debt several times. Hence Wu asked for professional debt collector Du Zhihao along with others to collect the debt from Su. The thugs provoked troubles in the factory of Su and detained her and her son, Yu Huan, threatening and beating them violently. Police were called to the scene but things did not work out. Finally, Yu Huan attacked Du and other three henchmen with a knife, causing Du's death and others' injury. This case has brought furious attention to the issues of private lending and violent debt collection.

Private lending has the characteristics of low threshold and fast flow [2]. On the contrary, bank loans require to go through complicated application assessment process and auditing procedure, which controls the business risks more strictly. As a result, small and medium enterprises (SMEs) are not likely to get the large amount of loans from banks even though they have met the basic requirements to get the mortgage. Hence, SMEs tend to choose private lending as their prompter way to get the large amount of loans from private lending in order to expand their business. However, private lending is always accompanied with high rate of return, which is also called the "usury". Basically, the debtor and creditor agree to have way higher return rate than the normal loans, which means the debtor have to take higher pressure when getting the large sums of money from the creditor. Therefore, there are always unfair situations where the amount of interests returned are way higher than the amount of capital lent. Once the capital chain of the debtor is broken that the interests cannot be paid, the creditor has to take high business risk. In order to collect the debt, creditors will seek for the help from professional collectors who will use various of methods, including the violent means, to get the money back. 


\subsection{The legislative definition, composition and boundary of private lending}

"Private lending”, compared to "official lending”, means the lending activities and financial intercourse behaviors between natural person and natural person, natural person and legal representatives, and among other organizations, instead of among the financial institutions that have been approved by the state financial regulatory authorities to engage in the lending business.

\subsubsection{The composition of private lending}

(1) Subject

The Supreme People's Court promulgated the "Provisions on Several Issues Concerning the Application of Law in the Trial of Private Lending Cases". [4] The main scope of the private lending behavior is clearly defined: The term" private lending "as mentioned in these provisions refers to mutual financial intercourse behaviours among natural person, legal representatives, other organisations.

(2) Object

The object of private lending is the lending contract, which refers to the written or verbal agreement that indicates the amount, subject matter, term, interest rate and other important information that are agreed by the debtor and the creditor.

(3) ontent

In the judicial practice, the lending activities occurred among natural persons and non-financial organizations are defined as "private lending". Private lending is a kind of civil legal act, which is the contract behavior between the debtor and the creditor, under the precondition that the the return of money should be the actual payment of the lending object and the object matter has to belong to the owner with the deposition.

\subsubsection{Boundaries of private lending (Key components)}

The following requirements should be met to form the private lending behavior:

(1) Conclusion of written or oral contract

The Article 197 of “Contract Law of the People's Republic of China” clearly states that parties in private lending can conclude the agreement in writing, or orally, by the form of receipt of loan, lending contract or verbal agreement, in order to confirm relevant information.

(2) Parties concluding a contract should share the same meaning and should possess the relevant capacity for the civil rights and for the civil acts.

The parties of private lending should possess the ability to fully understand the nature of the lending contract and the consequences of the law. Each side should sign the contract consciously and be aware that they should be responsible for their actions. Also the parties must sign the contract voluntarily after understanding the terms, rather than making a contract in the event of being deceived.

(3) Parties should perform their obligations as agreed

Whether the parties belong to debtor-creditor relationship, the amount of lending, the object matters and the term of lending are all defined by the written or oral agreement concluded by both sides. As long as the contents of the agreement are legal, they are all allowed and protected by the law. The creditor may require the debtor to pay interest at the time of repayment only if he or she has agreed in advance of the written or oral agreement.

\subsection{The legal connotation of violent debt collection}

Violent debt collection can be analyzed by dividing it into "violent" and "debt collection". Violence is the approach, which refers to the enforcement taken by the debt collectors that will cause physical and psychological damage on the debtor [3]. "Debt collection" is the purpose, which means the debt collector performs the obligation for the creditor to the debtor. 


\subsubsection{The reason of violent debt collection}

According to relevant laws and regulations of China, the interest rate agreed upon by both parties cannot surpass $36 \%$ of the annual interest rate, the exceeded part should be invalid. Therefore, the common borrowing interest rate in private lending is obviously too high, and the creditor cannot ask for the capital and all the interest back through legal means, so that they have to seek professional debt collectors to solve the contradiction. In addition, if going through the litigation process, it takes the court a relatively long time to file, investigate and go through other complicated processes, not to say when encountering dissenting opinions, second instance or other situations, the process will last longer. The high amount of litigation fee, attorney fee and the low efficiency of court will hinder the willing of creditors to get the payment back via legal means. In contrast, professional debt collectors, while using rugged means, can solve problems more efficiently.

\subsubsection{Common approaches of violent debt collection}

Professional debt collectors use various means to exert pressure on debtors, and their means are diverse and often violate the law. Some debt collectors build complex network of contacts and put pressure on debtors and their stakeholders. Some debt collectors call the ruffian rogue, to cause troubles at the debtor's home or their company, affecting normal life and work. Some debt collectors come to extortion, and even kidnapping the detention of relevant personnel, forcing the debtor to pay back the money. Professional debt collection organizations are complicated consisted by people who do not have any occupations or even gangsters. They always take intimidation, harassment, long-term stalking, restrictions on personal freedom, beating and other illegal means to force debtors to pay off debts. They are guilty of organizing, leading the crime syndicate, assaulting, illegal detention, provocation, extortion, fraud and so on.

\section{Analysis of Domestic and Foreign Research on Violent Debt Collection}

\subsection{Analysis of domestic research on violent debt collection}

Long Muxing and Mo Desheng from Guangdong Public Security Judicial Management Cadre College, by studying the social security issues caused by the Pearl River Delta region "Da Er Ku" case, analyzed the causes of violence debt collection, and made a few suggestions: those who use violence in the debt collection process and cause serious bad consequences, should be regarded as the principal in crime and be severely punished; the judicial cadres who corrupt, participate in or indulge the behavior of violent debt collection should be punished and fired. The government should vigorously strengthen the ban on gambling, eliminate rogues and gangsters, in order to stop and to reduce violent torture criminal activities.

Yang Haiyan, from Ocean University of China, questioned whether the creditor's use of violence in the debt collection process belongs to the offence of robbery, and put forward her own views on whether the creditor has the purpose of "illegal possession" [5]. She believes that whether the act of violent debt collection constitutes a crime of robbery needs to be further analysed by theoretical research on the issue of illegality and accountability.

\subsection{Analysis of foreign research on violent debt collection}

Anglo-American law countries attach great importance to human rights. Early Anglo-American law countries widely allowed creditors to exercise their rights, even regardless of whether they were using legal ways to do it. "The United States Model Penal Code" contains the requirement that the perpetrator can claim their rights in respect of the property or service. Those are with good faith or by knowing they have the right to acquire or dispose of the matter. According to this provision, the perpetrator, based on their right to claim, obtaining other people's property through improper means as a positive defense of the facts, can resist the establishment of crime. With the development of thought, Anglo-American countries began to pay attention to whether the act in the process of claim is legal. After the 1970s, the United States courts punished a number of so-called cases of exercise of power. 


\subsection{Current issues in the legal mechanism of violent debt collection in China}

First of all, in violent debt collection, creditors and the debt collectors cannot be seen as the same subject. Creditor owns the right to claim the debt from the debtor, yet debt collector does not. In practice, the debt collector used violent means to violate the debtor's personal rights and property, but it is difficult to define whether the acts of non-direct actor, which is the creditor, violated the debtor's rights.

Second, some of the behaviors of the debt collector in violent debt collection forcing the debtor are in the margin of the law, such as public stalking, which can cause psychological oppression, is difficult to be regulated. In the case of "Yu Huan", the debt collectors' behavior insulting the debtor are noticeably slight and do not constitute a crime, yet they have caused very serious physical and mental harm to the debtor [6].

Such behaviors of the debt collector are also difficult for police to deal with. They always deny when get caught stalking people, that police can only detain them instead of sentencing them. At the same time, since the debtor default the debt, the police also have the responsibility to urge them to pay back the money, which would put police in a dilemma.

In addition, the violent debt collection case is linked by many small cases, the victim of one case is the perpetrator of another case, so that the legal relationship and legal facts are complicated. The case of "Yu Huan" involves usury, breach of contract, debt collection, personal injury and other cases, the results of each case is the next sub-case of the matter, hence it is difficult to sort out which party should take the responsibility.

\section{A Case Study and Jurisprudential Analysis on the Violent Debt Collection in Private Lending}

\subsection{The Case Study and Legal Analysis on the Defaulting Process of Su Yinxia}

Su severely lost her credit and could not legally obtain loans from the bank, hence she started to get money by borrowing usury, and signed a real estate mortgage loan contract with high interest rate. Yet she did not have the ability to pay back the money when the contract is out of term. According to Article 196 of the Contract Law, a loan contract is a contract whereby the borrower borrows from the lender, who returns the loan and pays interest. Su and $\mathrm{Wu}$ signing the private lending contract can be regarded as a loan contract. According to Article 107 of the Contract Law, $\mathrm{Su}$ did not return the arrears at maturity and fail to fulfil the contractual obligations. However, according to the clause 2 of Article 211, the interest rate of the contract signed by Su and Wu was in violation of the relevant provisions of the state, hence the exceeding part does not have to be paid.

\subsection{The Case Study and Legal Analysis on the Violent Debt Collection Process of Du}

Du accepted Wu's commission of claiming the debt from Su so that he, along with a dozen people, broke into the factory of Su to stir up trouble, barbecue, forced Su to pay back the money. According to "Criminal Law" Article 293, it was a typical provocative behaviour. Du then detained $\mathrm{Su}$ and his son in the reception room, beating and insulting them physically and mentally, which has been suspected of illegal. According to Article 238 of the Criminal Law, Du and others were guilty of illegal detention, and should be severely punished since their behaviors involved beating, insulting.

\subsection{The Case Study and Legal Analysis of Yu Hurting Others}

When the police temporarily left the reception room to investigate the situation, $\mathrm{Yu}$ was in despair and was exasperated that he fought with Du and others, then stabbed them with a fruit knife grabbed from the table, resulting one dead and three injured. Yu clearly knew the fruit knife could cause harm to the human body but he still did so, which caused him guilty of intentional assault.

However, $\mathrm{Yu}$ and his mother's personal rights were in unlawful infringement, hence Yu's behavior was in the purpose to protect his mother, which belonged to legitimate defence. But since police had arrived at the scene, the behavior of $\mathrm{Du}$ and others have been unable to seriously 
endanger the safety of the two, thus Yu's legitimate defensive behaviour has obviously exceeded the limits and caused significant damage. According to Article 20 of "Criminal Law", Yu's behaviour was over defensive that he should be held criminally responsible, but should also be considered to be punished leniently or exempt from punishment.

\section{The Resolving Mechanism and Feasible Suggestions of Violent Debt Collection in Private Lending}

\subsection{The Resolving Mechanism of Violent Debt Collection based on the Constitution}

As the fundamental law of China, the Constitution constrains the behaviors of violent debt collection in many perspectives.

The first and third clause of article 37 in the Constitution states that the personal freedom of every Chinese citizen cannot be violated. Illegal detention and other means of illegally depriving or restricting the personal freedom of citizens and the illegal search of citizens' bodies are prohibited. Having inviolable personal freedom is the most fundamental right of each citizen, which is also the prerequisite for citizens to participate in various social activities and to enjoy other rights. Du and others seriously violated the debtor's personal freedom with all the behaviors mentioned above.

Article 33 of the Constitution states that the State respects and safeguards human rights. Human rights include the right to life, property rights, right of dignity and so on. Although the Constitution does not make clear provisions on the right to life and health, the right to life and health is the most basic personal rights of citizens and is undoubtedly protected by the Constitution. Du and others beat $\mathrm{Su}$ and $\mathrm{Wu}$, which violated the debtors' life and health rights.

Article 13 of the Constitution clarifies that the legitimate private property of a citizen is inviolable. The State protects the private property rights and inheritance rights of citizens in accordance with the law. Property rights are the very important economic rights conferred on citizens by the constitution and are the material basis for citizens to exercise other rights freely. Du, who provoked trouble to destroy the property of the factory, and to force Su for the purpose of getting back the money, has violated the legitimate property rights which are under the protection of the Constitution.

\subsection{The Mechanism of Violent Debt Collection Behavior Based on Civil Law}

There are specific provisions in civil law in terms of violent debt collections.

The debt collectors infringe the reputation of the debtor. The right of reputation is to maintain the reputation of human dignity. It is an important element of personality rights, which is protected by the law. Article 101 of the Civil Code states that citizens, legal persons enjoy the right of reputation, the dignity of citizens is under protection of the law. Insult, defamation, and other behaviors which damage the reputation of citizens are strictly banned. Du, who deliberately belittled Su through words, violence and other bad behaviors, has constituted a violation of the right to reputation.

The debt collectors infringe the privacy of others. The right to privacy refers that a person's private life and private information is protected by law, which cannot be infringed, known, collected, used or made public by others. According to China's national conditions and the relevant provisions of the "Tort Law of People's Republic of China" , illegal invasion, illegal stalking, illegal investigating other people's property status are violation of privacy.

However, in order to fundamentally solve the problem of violent debt collection, the civil law of China should also constraint the behaviors of the debtors while regulating the debt collectors, such as strengthening the intensity of urging the the debtor to pay the debt. At the same time, it should also speed up and simplify the legitimate auction of debtor assets, to ensure that creditors can quickly and easily exercise their right through legal channels and can abandon the violent debt collection or such illegal means. Optimizing the social credit publicity system is also very important to stop the diehard debtors concealing information when signing a loan contract. 


\subsection{The Mechanism of Violent Debt Collection Behaviour Based on Criminal Law}

Criminal law has made a number of provisions, constraints and regulations in regard to violent debt collection from different perspectives, providing rules to follow when solving the cases of violent debt collection.

The debt collector violated the illegal detention clause under the criminal law. Illegal detention is a criminal act of detaining, confinement or other coercive means for the unlawful deprivation of liberty of others. In accordance with the provisions of Article 238, clause 1 and 2 of the Criminal Law, the person who has committed a crime of illegal detention shall be sentenced to three to ten years of imprisonment. If the death is caused, the person shall be sentenced to a fixed-term imprisonment of not less than 10 years. Du and other violent debt collectors need to be sentenced to 3-10 years of imprisonment based on the severity of the case.

The debtors also constituted crime of mandatory indecent assault, insult. Violence, coercion or other means to compel any person or insulting a woman shall be sentenced to a fixed-term imprisonment of no more than five years or detention under article 237, paragraph 1, of the Criminal Code. The behaviour of Du exposing his perineum has become an insult, although the plot was slight and does not constitute a suspected indecent assault, it still can be identified as the aggravated plot in unlawful detention.

The debt collectors constituted the crime of affray, which means arbitrary provocation, assault, harassment or arbitrary damage, occupation of public and private property, or stirring up trouble in public. People who constitutes this crime shall be sentenced to a fixed-term imprisonment of no more than five years, be arrested or controlled under the provisions of Article 293 of the Criminal Law. The ones who seriously undermine the social order for several times shall be sentenced to 510 years and be fined concurrently. Du and others should be sentenced to five years imprisonment, legal detention or control due to causing troubles in the factory.

Criminal law has a more clear conviction and sentencing on the implementation of violent acts of debt collection, but has no direct rules to punish the instructor of the violent debtor. In my point of view, the instructor clearly understands that the violence used by the debt collector is likely to harm the society yet is determined to entrust the debt collector to take the debt, subjectively hopes that the harmful consequences happen to the debtor, that he/she should be punished along with the debt collectors in accordance with the severity of the crime.

\section{Summary}

Through the research and analysis of this thesis, we summarized the legal application and resolving mechanism of violent debt collection in private lending. With the comprehensive application of constitution, civil law and criminal law, the legal liability of each violent debt collection case can be precisely identified, and these cases can be avoided at the legal level only if the

\section{References}

[1] Pan Shaoying. The Story of Yu Huan-Miserable Past of Private Lending. IT Times, 2017-0331 (002).

[2] Wen Zhijiang. Cutting-edge review of China's Criminal Law Concept. Chinese Journal of Criminal Law, 2015, (02): 3-22.

[3] Yang Haiyan. Violent Debt Collection Behaviour of the Criminal Law. China Ocean University, 2015.

[4] Zhang Qianfan. Discussion of the Constitutional Application [J]. Chinese and foreign law, 2012, (05): 887906.

[5] Yi Jun. New Interpretation of Civil Law Fairness. Jarist, 2012, (04): 54-73 + 177-178. 
[6] Yue Caishen. The Focus of Private Lending Regulation and Legislative Proposals. Chinese Journal of Law, 2011, (05): 84-96.

[7] Long Muxing, Mo Desheng. Preliminary Study of Folk Violence Debt Collection Journal of Public Security University, 1995, (02): 40-42. 